\title{
Study of influencing factors on the peak dissipation energy at physical simulation similar material of coal-rock solid-gas coupling
}

\author{
Zhao Peng-xiang ${ }^{1,2}$, He Bin-lei ${ }^{1}$, Xiao Peng ${ }^{1,2}$, \\ Yang Erhao ${ }^{1}$, Gao Jin-biao ${ }^{1}$ \\ ${ }^{1}$ College of Safety Science and Engineering, Xi'an University of Science \& \\ Technology, Xi'an 710054 China \\ ${ }^{2}$ Key Laboratory of Western Mine Exploitation and Hazard Prevention of \\ the Ministry of Education, Xi'an 710054 China
}

\section{Received December 20,2016}

Based on the study of the test specimens made with the new "solid-gas" coupling similar material, the variation rule of energy characteristics during the compression and rupture of rocks and the criterion to judge rock damage were obtained. The results show that during the process of uniaxial fracturing, the peak dissipation energy of the test specimen has a logarithmic relationship with the bone-glue ratio, while it has a positively correlated exponential relationship with the mass ratio of gas-barrier cementing agent. It was shown that the sensitivity of peak dissipation energy toward the mass ratio of gas-barrier cementing agent is more obvious. The research results have provided the theoretical basis for the quantified appraisal of the fracture evolution region. Keywords: bone-glue ratio; gas-barrier cementing agent; similar material; uniaxial fracturing; peak dissipation energy; sensitivity

На основании изучения образцов, полученных с использованием нового модельного материала близкого по характеристикам к твердофазному материалу, содержащему газовый фрлюид, установлены закономерности изменения энергетических характеристик при сжатии и разрыве горных пород, а также критерий для оценки повреждения породы. Результаты показывают, что в процессе одноосного разрыва пиковая энергия диссипации испытуемого образца имеет логарифмическую зависимость от относительного содержания костного клея, и положительно коррелированную экспоненциальную зависимость от массового соотношения газобарьерного цементирующего агента. Показано, что чувствительность пиковой энергии диссипации к величине фактора относительных массовых содержаний газобарьерного цементирующего агента более очевидна. Результаты исследования позволили теоретически обосновать количественные оценки в области эволюции трещин.

Дослідження факторів, що впливають на пікову енергію дисипації шляхом фізичного моделювання матеріалу, що імітуе вуглецевий твердотільний матеріал, що містить газовий флюїд. Чжао Пен-сян, Хе Бінь-лей, Сяо Пень, Ян Ерхао, Гао Цзінь-бяо

На підставі вивчення зразків, отриманих з використанням нового модельного матеріалу, близького за характеристиками до твердофразного матеріалу, який містить газовий фрлюїд, встановлені закономірності зміни енергетичних характеристик при стисненні і розриві гірських порід, а також критерій для оцінки пошкодження породи. Результати показують, що в процесі одноосного розриву пікова енергія дисипації випробуваного зразка має логарифмічну залежність від відносного вмісту кісткового клею, і позитивно корелювали експонентну залежність від масового співвідношення газобарьерного цементуючого агента. Показано, що чутливість пікової енергії дисипації до величини фрактора відносних масових змістів газобарьерного цементуючого агента більш очевидна. Результати дослідження дозволили теоретично обгрунтувати кількісні оцінки в області еволющії тріщин. 


\section{Introduction}

With the continuous increasing of coal mining depth, gas disaster happens more frequently because of the influences from the multi-physical fields of mining. Thus, finding a method to describe the dominant channel of gas in the mining fracture field and the range of gas enrichment areas so as to realize the efficient control and utilization of gas has become extremely urgent. Currently, many scholars at home and abroad have carried out a large amount of research from different perspectives [1-20] but it hasn't conducted in-depth research on the energy release rule of the "solid-gas" coupling similar material during the process of fracturing. Therefore, this paper has analyzed the energy dissipation characteristics as well as their sensitivities of test specimens made with the existing proportions of "solid-gas" coupling similar material under uniaxial loading condition, which will provide certain theoretical basis for subsequent research to conduct the twodimensional mining induced crack evolution in enclosure space and identify the range of areas of development in the rock stratum during the gas migration coupling physical similarity simulation experiment. It will also provide certain basis for perfecting the multi-physical field coupling during mining, as well as the theory and technical system for the simultaneous extraction of coal and gas.

\section{Experimental Scheme and Samples}

\subsection{Experimental Scheme}

In order to study the influence rule of the two factors, A (the bone-glue ratio) and $\mathrm{B}$ (the mass ratio of gas-barrier cementing agent) on the peak dissipation energy of the test specimens made with the new "solid-gas" coupling similar material during the process of uniaxial fracturing. 5 proportions have been selected for the bone-glue ratio and the mass ratio of gasbarrier cementing agent respectively to design a total of 25 groups of experiments for the analysis and research. See Table 1 for the experimental design.

\subsection{Experimental Samples}

The similar materials for making the test specimens are the new "solid-gas" coupling similar materials self developed and produced by the laboratory. The materials contain river sand, cement, amylum and Bone-Glue. The similar material test specimens are made with the dimension of $\mathrm{D} Y \mathrm{~h}=50 \mathrm{~mm} Y 100 \mathrm{~mm}$ with the self-made double-open-ended cylinder mould (see Figure 1). To avoid the influences of other controllable factors on the experiment
Table 1 Experimental design for the energy dissipation of test specimens made with the new "solid-gas" coupling similar material

\begin{tabular}{|c|c|c|c|c|c|c|}
\hline No. & \multicolumn{6}{|c|}{ Factor } \\
\hline 1 & $1: 10$ & 0.015 & 0.026 & 0.035 & 0.041 & 0.045 \\
\hline 2 & $1: 20$ & 0.015 & 0.026 & 0.035 & 0.041 & 0.045 \\
\hline 3 & $1: 30$ & 0.015 & 0.026 & 0.035 & 0.041 & 0.045 \\
\hline 4 & $1: 40$ & 0.015 & 0.026 & 0.035 & 0.041 & 0.045 \\
\hline 5 & $1: 50$ & 0.015 & 0.026 & 0.035 & 0.041 & 0.045 \\
\hline
\end{tabular}

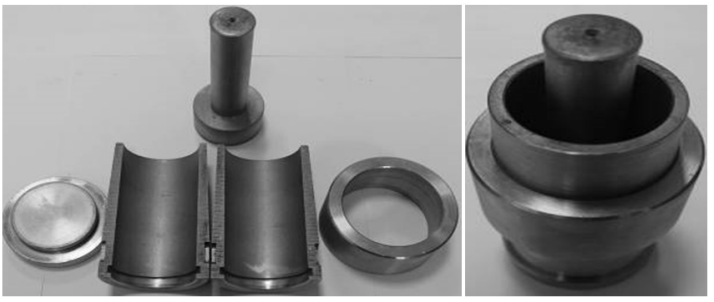

Fig. 1 Double-open-ended cylinder mould

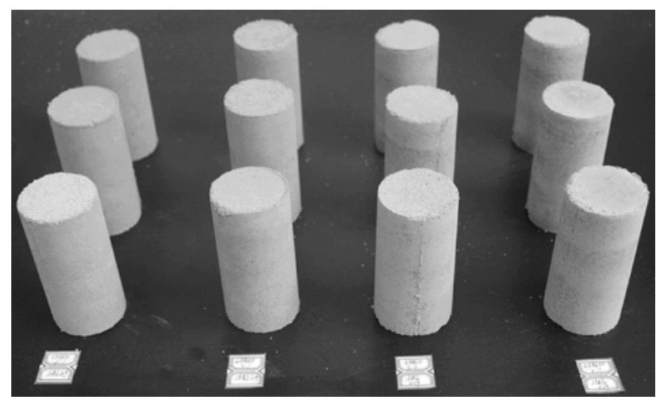

Fig. 2 Part of the experimental samples

results during the process of test specimens production, it is required that during the process of test specimens production, all these factors should be the same. It is mainly required that during the process of test specimens production, each test specimen should go through average material loading for three times, the weight of the mixing material in each loading is $1 / 3$ of the weight of the entire test specimen, and the impact height of each heavy punch is $1.5 \mathrm{~m}$. Part of the produced experimental samples are shown in Figure 2.

\section{Experimental facility and proce- dures}

\subsection{Experimental Facility}

The experiment has adopted SAEU2S multichannel acoustic emission system to test the energy dissipation characteristics of the similar material test specimens at the peak value during the process of fracturing. Through the 
environmental noise test, the threshold value has been set at $50 \mathrm{~dB}$ and the sampling rate is 4000. Each channel corresponds to an independent acoustic emission probe and a preamplifier. The magnification of the signal amplifier is 40 times. In order to avoid the influence of the friction between the squeeze head and the end face of the test specimens on the experiment, couplant has been applied to the contact surfaces of the probes and the rock surfaces.

The experiment has adopted the YYW-II-EX (Extensometer) stress gauge, as the loading facility to test the mechanical properties of the test specimens. This facility is composed of lever extensometer, base, stress ring, dialgauge, jack, loading board, cranking bar, dialgauge, frame, etc and the loading methods include manual loading and electric loading. When the electric loading is implemented, the loading rate is $1.13 \mathrm{~mm} / \mathrm{min}$; the equal shift loading method is adopted to carry out the uniaxial fracturing on the similar material test specimens, and the acoustic signal acquisition and the rock loading are carried out simultaneously.

\subsection{Experimental Procedures}

The specific experimental procedures are as follows:

(1) Fix the acoustic emission sensor to the center of the surface of ready-made new similar "solid-gas" coupling similar material test specimens with cellulose tape. Turn on the acquisition instrument and open the software to test the environment noise and determine the threshold value. Enter the parameter values of the acoustic emission;

(2) Place the "solid-gas" coupling similar material on the base of the YYW-II-EX unconfined pressure meter. Turn on the electric reel of the YYW-II-EX unconfined pressure meter. Adjust the meter to make the initial value of the stress ring as zero. Record the initial values of the lever extensometer and the axial displacement dialgauge;

(3) Turn on the electric loading of the YYWII-EX unconfined pressure meter, record the readings on the dialgauges of the lever extensometer and the stress ring upon every two rounds of the reel.

(4) Keep loading and recording the data until the test specimens made with the new "solidgas" coupling similar material fractures, then continue the experiment of next group;

(5) Sort out the experimental data with the methods of linear regression and analysis of variance.

\section{Experimental Results and Analysis}

\subsection{The Influence of Bone-Glue Ratio on}

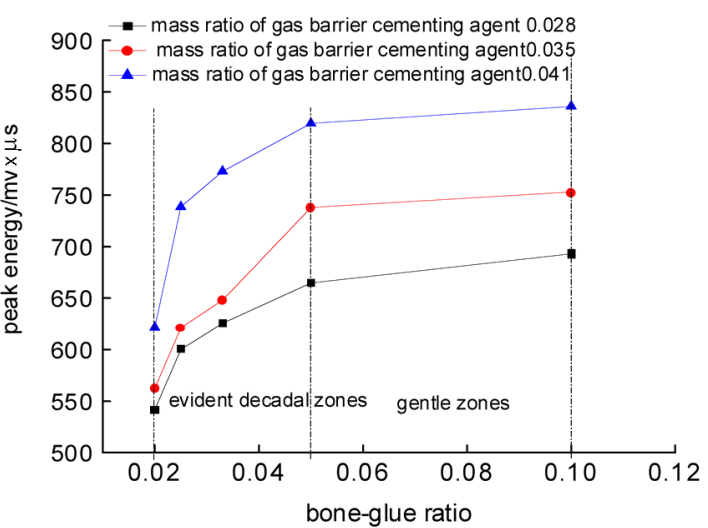

Fig. 3. The relationship between the peak dissipation energy of part of test specimens during the fracturing and bone-glue ratio

\section{the Peak dissipation Energy of the "Solid- Gas" Coupling Similar Material}

Selecting three groups of test specimens with the typical proportions from the data of the test specimens made with the new "solidgas" coupling similar material during the process of fracturing collected by the acoustic emission for analysis, we got the relationship curves between the peak dissipation energy of the test specimens made with the new "solid-gas" coupling similar material during the process of fracturing and the bone-glue ratio, which has been shown in Figure 3.

From Figure 3, it can be seen that the peak dissipation energy of the test specimen during the process of fracturing increases gradually as the bone-glue ratio increases. The peak dissipation energy of the test specimen during the process of fracturing increases rapidly when the bone-glue ratio is in the range of 0.02 0.05, which lies in the significance zone; and its increase tends to be gentle when the bone-glue ratio is in the range of $0.05 \sim 0.1$, which lies in the gentle zone. Through the above analysis, it can be concluded that $0.02 \sim 0.05$, namely the significance zone, is the range in which the bone-glue ratio has greater influence on the peak dissipation energy dissipation of the test specimens made with the new "solid-gas" coupling similar material.

By fitting the relationship curves obtained in Figure 3, the relation between the peak dissipation energy of the test specimens made with the new "solid-gas" coupling similar material during the process of fracturing and the bone-glue ratio can be obtained, which is shown in Table 2.

From the fitting results in Table 2 , in can be seen that relationship between the peak dissipation energy of the test specimens made with the new "solid-gas" coupling similar material during the process of fracturing and bone-glue 
Table 2 The fitting relationship between the peak Dissipation energy of part of test specimens during the fracturing and bone-glue ratio

\begin{tabular}{|c|c|c||}
\hline No. & Fitting Relation & $\begin{array}{c}\text { Fitting } \\
\text { Degree }\end{array}$ \\
\hline 1 & $E_{1}=789.211+37.578 \mathrm{Lnx}_{\mathrm{A}}$ & $\mathrm{R}^{2}=0.992$ \\
\hline 2 & $E_{1}=914.599+60.176 \mathrm{Lnx}_{\mathrm{A}}$ & $\mathrm{R}^{2}=0.902$ \\
\hline 3 & $E_{1}=937.011+37.226 \mathrm{Lnx}_{\mathrm{A}}$ & $\mathrm{R}^{2}=0.984$ \\
\hline
\end{tabular}

ratio is applied to the following logarithmic function relationship:

$$
E_{1}=a_{1}+b_{1} \ln \left(\mathrm{x}_{A}\right)
$$

where, $E_{2}$ is the peak dissipation energy of the test specimens made with the new "solid-gas" coupling similar material during the process of fracturing; $x_{\mathrm{A}}$ is the bone-glue ratio of the test specimen; $a_{1}, b_{1}, c_{2}$ are fitting constants, which are determined by the inherent properties and manufacturing techniques of the materials of the test specimens made with the new "solidgas" coupling similar material.

\subsection{The Influence of the Mass Ratio of} Gas-Barrier Cementing Agent on the Peak Dissipation Energy of the Similar Material

Without changing the bone-glue ratio, select three groups of test specimens with the typical proportions for analysis. The relationship curve between the peak dissipation energy of the test specimens during the process of fracturing and the mass ratio of gas-barrier cementing agent can be obtained, which is shown in Figure 4.

From Figure 4, it can be included that when the mass ratio of gas-barrier cementing agent is $0.015 \sim 0.035$, the peak dissipation energy of the test specimens increases relatively slowly during the process of fracturing, which lies in the gentle zone; and when the mass ratio of gas-barrier cementing agent is $0.035 \sim 0.045$, the peak dissipation energy increases rapidly during the process of fracturing the test specimens, which lies in the significance zone; Thus it can be seen that the application of the gas-barrier cementing agent can increase the peak dissipation energy during the process of fracturing the test specimens in different degrees; when the bone-glue ratio of the test specimen is fixed, the higher the mass ratio of gas-barrier cementing agent is, the bigger the peak dissipation energy will be during the process of fracturing the test specimens.

By fitting the curves in Figure 4, the fitting relation between the changes of the uniaxial fracturing peak dissipation energy of the test specimens made with the new "solid-gas" cou-
Table 3. The fitting relation between the peak Dissipation energy of part of test specimens during the fracturing and the mass ratio of cementing agent

\begin{tabular}{|c|c|c|}
\hline № & Fitting Relation & $\begin{array}{c}\text { Fitting } \\
\text { Degree }\end{array}$ \\
\hline 1 & $E_{2}=567.241+0.956 \exp \left(124.035 \mathrm{x}_{\mathrm{B}}\right)$ & $\mathrm{R}^{2}=0.964$ \\
\hline 2 & $E_{2}=586.177+0.561 \exp \left(140.629 \mathrm{x}_{\mathrm{B}}\right)$ & $\mathrm{R}^{2}=0.980$ \\
\hline 3 & $E_{2}=507.566+63.332 \exp \left(37.297 \mathrm{x}_{\mathrm{B}}\right)$ & $\mathrm{R}^{2}=0.962$ \\
\hline
\end{tabular}

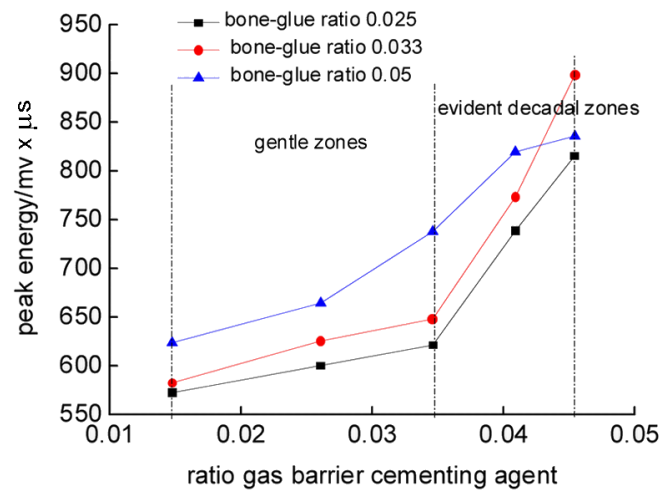

Fig. 4. The relationship between the peak dissipation energy of part of test specimens during the fracturing and the mass ratio of gas-barrier cementing agent

pling similar material and the mass ratio of gas-barrier cementing agent can be obtained, which is shown in Table 3.

From Table 3, it can be concluded that the mass ratio of gas-barrier cementing agent and the peak dissipation energy during the process of fracturing are in accordance with the following exponential relationship:

$$
E_{2}=a_{2}+b_{2} \exp \left(c_{2} x_{B}\right)
$$

In the formula, $E_{2}, x_{B}$ are the peak dissipation energy of the test specimen made with the new "solid-gas" coupling similar material during the process of fracturing and the mass ratio of gas-barrier cementing agent of the test specimen respectively; $a_{2}, b_{2}, c_{2}$ are constants, which are related to the production process and materials of the test specimens made with the new "solid-gas" coupling similar material.

\subsection{Sensitivity Analysis of Influencing}

\section{Factors for the Peak Dissipation Energy}

Sensitivity refers to the degree to which uncertain factors influence the target factors. In order to study the sensitivity of the influence of two factors, the bone-glue ratio and the mass ratio of gas-barrier cementing agent, toward the peak dissipation energy of the test specimens made with the new "solid-gas" coupling 
Table 4. Table of variance analysis on the factors influencing the peak dissipation energy of the test specimens during the process of fracturing

\begin{tabular}{|c|c|c|c|c|c|}
\hline & $\begin{array}{c}\text { Sum of squares of } \\
\text { errors }\end{array}$ & Degree of freedom & Mean square & F Value & $\begin{array}{c}\mathrm{F}_{0.05} \\
(4,16)\end{array}$ \\
\hline A & 60464.30 & 4 & 15116.07 & 14.70 & 3.01 \\
\hline B & 215218.44 & 4 & 53804.61 & 52.31 & 3.01 \\
\hline Error & 16458.46 & 16 & 1028.65 & & \\
\hline
\end{tabular}

similar material during the process of fracturing, the experiment has adopted the variance analysis in mathematical statistics to analyze the sensitivity of the two factors to the peak dissipation energy during the process of fracturing the test specimens, the analysis procedures of this analysis method are as follows:

The variance of the row factor and the column factor:

$$
\begin{aligned}
S S R & =\frac{\sum_{i=1}^{k} r\left(\bar{x}_{i \underline{~} \downarrow}-\overline{\bar{x}}\right)^{2}}{k-1} \\
S S C & =\frac{\sum_{j=1}^{r} k\left(\bar{x}_{\sharp j}-\overline{\bar{x}}\right)^{2}}{r-1}
\end{aligned}
$$

Sum of squares of the errors

$$
S S E=\sum_{i=1}^{k} \sum_{j=1}^{r}\left(x_{i j}-\bar{x}_{i \cdot}-\bar{x}_{\cdot j}+\overline{\bar{x}}\right)^{2}
$$

Mean square of the row factor and column factor:

$$
\begin{aligned}
& M S R=\frac{S S R}{k-1} \\
& M S C=\frac{S S C}{r-1}
\end{aligned}
$$

Test the statistics of the row factor and the column factor:

$$
\begin{gathered}
? F_{R}=\frac{M S R}{M S E} \sim F(k-1,(k-1)(r-1)) \\
? ? ? F_{R}=\frac{M S C}{M S E} \sim F(r-1,(k-1)(r-1))
\end{gathered}
$$

The analysis results indicate that the variance analysis of the two factors on the peak dissipation energy of the new "solid-gas" coupling similar material during the fracturing is shown in Table 4

It can be seen from Table 4 that $\mathrm{F}_{\mathrm{B}}>\mathrm{F}_{\mathrm{A}}>$ $\mathrm{F}_{0.05}(4,16)$, which shows that both Factor $\mathrm{A}$ (the bone-glue ratio) and Factor $\mathrm{B}$ (the mass ratio of gas-barrier cementing agent) have significant influences on the peak dissipation energy of the new "solid-gas" coupling similar material during the process of fracturing. And since $\mathrm{F}_{\mathrm{B}}>\mathrm{F}_{\mathrm{A}}$, the influence of Factor $\mathrm{B}$ on the peak dissipation energy of the "solid-gas" coupling similar material during the process of fracturing is more significant than that of Factor A, which shows that the mass ratio of gas-barrier cementing agent plays a major controlling function on the peak dissipation energy of the test specimens made with the new "solid-gas" coupling similar material during the process of fracturing.

\section{Conclusion}

(1) The experiments have proved that the bone-glue ratio of the test specimens made with the new "solid-gas" coupling similar material has the logarithmic relationship with its peak dissipation energy during the process of fracturing and that when the bone-glue ratio is in the range of $0.02 \sim 0.05$, the peak dissipation energy during the process of fracturing the test specimens lies in the significant zone; and when it is in the range of $0.05 \sim 0.1$, the peak dissipation energy lies in the gentle zone.

(2) The experiments have proved that the peak dissipation energy of the test specimens made with the new "solid-gas" coupling similar material has an exponential relationship with their mass ratio of gas-barrier cementing agent during the process of fracturing, and that the peak dissipation energy of the test specimens made with similar material during the process of fracturing increases as the mass ratio of gasbarrier cementing agent increases. When the mass ratio of gas-barrier cementing agent of the test specimens is in the range of $0.015 \sim 0.035$, the peak dissipation energy of the test specimens during the process of fracturing lies in the gentle zone; and the significance zone lies in the range of $0.035 \sim 0.045$.

(3) After analyzing the sensitivity of the bone-glue ratio and the mass ratio of gas-barrier cementing agent for the peak dissipation energy of the test specimens made with the similar material during the process of fracturing by adopting the variance analysis in mathematical statistics, it can be concluded that the sensitivity of the mass ratio of gas-barrier cementing agent toward the peak dissipation energy of the test specimens during the process of fracturing is more obvious than that of the bone-glue ratio. 


\section{Acknowledgment}

This research was supported by the Basic Research on Scientific Instruments of the National Natural Science Foundation of China (51327007), National Natural Science Foundation of China (51474172, 51304156, 51604219), China Postdoctoral Science Foundation Funded Project (2016M602843), Xi'an University of Science and Technology breeding foundation (201651).

\section{Reference}

1. Su Cheng-dong, Zhai Xin-xian, Li Bao-fu, et al., J,Min,Safety Eng., 28(2): 225, 2011.

2. Wei Jialei, Liu Shanjun, Wu Lixin et al., J,Min, Safety Eng., 32(6),1017, 2015.

3. Cao Anye, Jing Guangcheng, Dou Linming et al., J. Min. Safety Eng., 32(6), 923, 2015.

4. $\mathrm{Mu}$ Kang, $\mathrm{Yu}$ Jin, Li Hong et al. Rock Soil Mech., 36(5),1496, 2015.
5. Zhao Fujun, Wang Hongyu, Peng Yun et al. Chinese J. Rock Mech.Eng., 31(7), 1363, 2012.

6. Lai Yushu, Xiong Yan, Cheng Longfei et al. J. Vibr. Shock, 33(10),177, 2014.

7. Gong Cong, Chen Hui, China Min.Mag, 23(10), 144, 2014.

8. Wan Guoxiang, Wang Qisheng, Li Xibing et al. J.Exp. Mech., 27(6), 727, 2012.

9. Lu Hongjian, Liang Peng, Gan Deqing, Zhang Songlin,Min. Res. .Develop., 36(04), 78, 2016.

10. Li Shugang, Zhao Pengxiang, Lin Haifei et al. J. Min. Safety Eng., 31(5), 750, 2014.

11. Lin Haifei, Zhai Yulong, Li Shugang et al. $J$. China Coal Soc., 41(3), 672, 2016. 